\title{
STŘEDOVĚKÉ KOVOVÉ „POLNÍ“، LAHVE NA PŘÍKLADU NÁLEZU Z HRADU RONOVCE
}

\author{
ALEŠ KNÁPEK - PAVEL MACKŮ
}

\begin{abstract}
Abstrakt: Ačkoli byly čutory běžné v prostředi středověké a novověké každodennosti, nebyl jim v české odborné literatuře zatím věnován větši prostor. Na hradě Ronovci byla v roce 1958 objevena kovová polní lahev, pro niž se podařilo dohledat analogie jak u nás, tak v zahraničí. Vzhledem k nedostatečné dokumentaci při exkavaci čutory byly pro její časové a sociálni souvislosti využity písemné a ikonografické prameny, které ukazuji na jeji široké využití ve vesnickém, měšt'anském, šlechtickém, ale třeba i poutnickém prostředí. Práce si neklade za cíl zcela prozkoumat danou problematiku, pouze otevř́t diskuzi, která by vedla k rozpoznání, at' už celých, či fragmentárních lahví ze starých archeologických výzkumů, či upozornit na jejich možné objevy při odborných exkavacích v budoucnu.
\end{abstract}

Klíčová slova: čutora-ploska-Feldflasche-Costrel-Ronovec.

\section{Medieval "field" metal water bottles on the example of a find from Ronovec Castle}

Abstract: Although water bottles were common everyday items in the Middle Ages and the modern age, until recently they have received little attention in Czech specialist literature. A metal water bottle was unearthed at the Ronovec castle in 1958 for which analogies were found both in this country and abroad. Owing to the lack of documentation from the excavation, written and iconographic sources were employed for the determination of its chronological and social context. They point to the wide use of these bottles in the rural, bourgeois, aristocratic and pilgrimage environments. Interestingly, the bottles often featured biblical and genre scenes. This article does not seek to explore the issue in its entirety but rather to start a discussion leading to the identification of complete bottles or their fragments among finds from previous excavations and to draw attention to their possible occurrence in the future.

Key words: water bottle - hip flask-Feldflasche-Costrel-Ronovec.

Přenosné nádoby na tekutiny určené k okamžité spotřebě jedince jsou součástí našeho života i v současnosti. Lidské tělo vydrží bez vody jen několik málo dní, ale značné problémy přivodí dehydratace člověku daleko dř́ve. Přestože neodvodněná středověká krajina byla na tekutinu bohatší než dnes, objevují se ikonografické i archeologické doklady užíání takzvaných polních lahví (Feldflasche, Costrel, ploska, hovorově čutora) poměrně hojně. Nezapomínejme totiž, že zvýšenou dehydrataci organismu způsobuje nejen horké, ale také mrazivé a větrné počasí. Pokusíme se čtenáři předložit příklad jedné unikátně dochované kovové středověké polní lahve a zasadit jej do kontextu současného poznání artefaktů tohoto druhu.

\section{Suroviny pro výrobu polních lahví}

Materiálů pro výrobu příručních lahví bylo v průběhu historie využíváno několik. K nejstarším patří nesporně keramika, ze které jsou vyráběny lahve již v klasických kulturách Středomoří (např. Kréta). Podobně je na tom dřevo, nebot' doklady z něj vyrobených lahví poskytují přinejmenším hrobové výbavy mladšího evropského pravěku a raného středověku (Dürrich 1846; Hrubý 1955, 161; Kaván 1962, 225, obr. 4:10-12, 228; Niederle 1933, 44-46). Pravděpodobně dřevěnou či usňovou čutoru lze zaznamenat na kamenné stéle zobrazující bojovníka z Niederdollendorfu (u Bonnu, SRN), vzniklé okolo roku 600 (Furger 1996, 202, obr. 221). Kůže je jako materiál pro výrobu čutor doložena v raném středověku v Sáze o Grettim (Heger 1957, 49). Irské národní muzeum vystavuje zdobenou usňovou čutoru z Cloonclose, kterou datuje obecně do raného středověku. Zdá se však, že může jít o výrobek o něco pozdější (No. 1928:12, k dataci Crone-Campbell 2005, 86). Stranou pro potřebu této studie zaměřené primárně na kovové nádoby ponecháváme problematiku míry dochování těchto dvou materiálů v archeologickém prostředí, což nepochybně ovlivňuje skladbu nálezového celku. 
První lahve na tekutiny vyrobené z barevného kovu se objevují v Evropě již od starší doby železné (Bissenzio la Buccace, podle Marzoli 1989, Tab. 9). Také římské vojenské prostředí znalo lahvičky ze železného plechu doplněného barevným kovem (např. nález ze studny u vojenského tábora z Rainau-Buch, podle Planck 1983, 160). Mezi dnes nejznámější kovové čutory pak jistě patří bohatě zdobená lahev (Reiseflasche) svatého Ruperta z konce 14. století. Tělo nádoby pod kovovým ozdobným pláštěm je však dřevěné (Tietze 1912, 54-55; Otruba 1970, 104). Ve středověku se vyskytují také lahve vyrobené z barevných kovů. Do 14.-15. století je datována bronzová čutorka ze Zalužan na Slovensku, zdobená iniciálami a erbem (Polla 1962, 145-146, obr. 112:17; nejnověji Soják 2015, 60, obr. 68). V Porýní se dochovaly středověké cínové polní lahve z druhé poloviny 15 . století, jejichž výroba je vzhledem $\mathrm{k}$ heraldickým motivům na plecích kladena do oblasti města Kolína nad Rýnem (Jung 1970, 23). Užívání barevných kovů, například mědi či cínu, se pro výrobu nádob postupem času zřejmě zvyšuje, jak naznačují písemné prameny (viz níže).

\section{Tvarová variabilita lahví}

Mimo rozdělení podle použitého materiálu existuje také několik základních tvarů. Nejčastější jsou kulaté zploštělé tvary, typicky pro kovové, keramické a dřevěné soustružené kusy, nebo tvary soudkovité s různou formou průřezu (kulaté, oválné, trojúhelné) pro usňové a dřevěné dýhované výrobky. V raném novověku je morfologie už značně rozvolněná, byt' stále vychází $\mathrm{z}$ osvědčených tvarů.

Pro kovové čutory byl nejčastěji užíván praktický tvar běžný jak u keramických a dřevěných, tak i usňových kusů. Jde o zhruba kruhové tělo nádoby, jehož líc je více či méně vydutý. Rub, tedy strana přiléhající k tělu nosiče (osoby nebo zvířete) bývá zřejmě z praktických důvodů zploštělá. Především v německých sbírkách jsou také zastoupeny kovové a usňové lahve složené ze dvou vydutých ploch připojených ke středovému pásu. Zástupcem tohoto tvaru je nález z př́ikopu švýcarského hradu Hallwyl (obr. 7:4). Tyto baňaté tvary jsou obvyklejší s nástupem novověku u tzv. loveckých lahví (k vidění v expozici SZ Žleby, MWP Varšava, NM Berlin), ale jeden exemplář vidíme také v ležení Karla V. před Lauingenem v dobové ikonografii (obr. 6:E). Na horní straně jsou tyto nádoby opatřeny trychtýřovitým nebo válcovým ústím, prŕípadně uchy. Spodní strana je někdy zploštělá nebo opatřená nožkami pro větší stabilitu nádoby. Po bocích bývají často umístěny aplikace $\mathrm{k}$ protažení nosného řemínku. V raném novověku se pak tělo nádoby více zaobluje a bývá opatřeno nožkami, a to dokonce např́íklad u usňové čutory v Germanisches Nationalmuseum, inv. č. HG10576.

\section{Výrobci - flašnéři}

Výrobou kovových lahví se zabývali ve středověku flassneri, flaškariové. Později se z nich vydělili klempíri, pracující jen s bílým plechem. „Ti z plechu robili flaše, nádoby a všelico $k$ domovité potřebě (...)“ (Winter 1906, 148). Písemně je ve středověkých Čechách výrobce lahví flašnéŕ doložen např́iklad v Táboře (Hejna 1970, 28). Flašnéři (arsflaškariorum) měli dle Wintera v 15. století pracovat také s lucernami a ,hotovili (...) také všelijaké nádoby z plechu černého i z bílého" (1890, 568). Z venkovského prostředí jejich výskyt neznáme, ale například chebští byli roku 1498 zváni na Pražský hrad kvůli pobití pěti střech pocínovaným (!) plechem. V Praze žilo v lucemburské éře patnáct flašnéřů (ovšem v letech 1424-1526 jen dva), přičemž dnešní Spálená ulice se dříve jmenovala Flašnéřská - ,vicus flassneriorum“ (Winter 1906, 148, 458). Roku 1514 se pražský mistr Duchek uvádí již počeštěně jako lahvičník (Winter 1906, 458). V polovině 16. století se pražští ,flašnýři“ zmiňují vedle konvářù (Winter 1890, 568). 

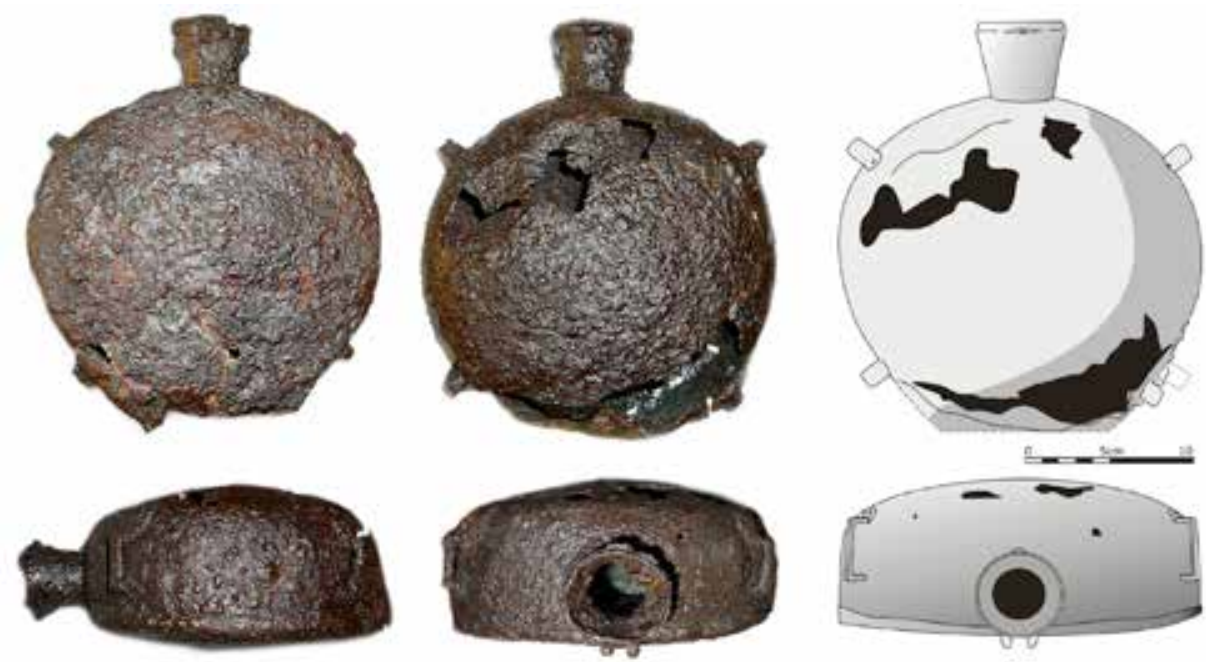

Obr. 1. Fotografie a nákres kovové lahve nalezené na hradě Ronovec (okr. Havlíčkův Brod) v květnu 1958. Foto a kresba A. Knápek, upravil P. Macků.

Abb. 1. Fotografie und Aufrisszeichnung der auf Burg Ronovec im Mai 1958 gefundenen Metallflasche (Bezirk Havlíčkův Brod). Foto und Zeichnung A. Knápek, bearbeitet von P. Macků.

\section{Lahev z hradu Ronovce a její známé analogie}

Přestože jsou doklady užívání lahví v dobové ikonografii relativně běžné, nejsou v českých sbírkách středověké lahve příliš zastoupeny. Může ovšem jít jen o nedostatečnou pozornost $\mathrm{s}$ jejich publikací či jejich nerozpoznání v př́ípadě, že jde o fragmentární kus. Poměrně unikátním objektem je proto polní lahev nalezená v 50. letech 20. století na hradě Ronovci (okr. Havlíčkův Brod). O to víc je ku škodě věci, že nálezové okolnosti jsou bohužel známy jen zhruba. Lahev byla nalezena u obvodové hradby jádra poblíž takzvané studny na jihozápadní straně nádvoří v hloubce asi $45 \mathrm{~cm}$ (obr. 2).

Josef Čapek zmiňuje dva možné, oddělené středověké archeologické horizonty, jež ovšem nebyly dosud vzájemně kriticky zhodnoceny. Byt' neznáme provozní účel budovy, předpokládáme ze skladby nálezů, že přinejmenším v mladší fázi svého života měla co do činění s militární a provozní složkou života hradu (například ubytování nebo sklad). Dokládá to spolu s pojednávanou lahví např́iklad nález části ochranné zbroje (Knápek-Macků 2016).

Nádoba je vyrobena z železného, snad pocínovaného plechu (dle Čapek 1958, 32-35 včetně plánku; k výzkumům na hradě Knápek 2019). Vzhledem k někdejšímu konzervačnímu postupu se není možné zatím vyjádřit k př́ípadným dalším použitým kovům ani jejich analýze. Nádoba je tvořena kruhovým tělem, které je směrem k základně kónicky protaženo a zploštěno tak, že vytváŕí rovnou podstavu (obr. 1). Na horní části je osazeno kuželovité ústí s panty pro uchycení nedochované záklopky. Výška nádoby činí asi $20 \mathrm{~cm}$ plus $4,5 \mathrm{~cm}$ vysoké hrdlo. Tělo nádoby tvoří dva velké kusy plechu. Čelní je vyklepán do tvaru hluboké misky. Zadní díl je jen mírně prohnutý a jeho okraj je ohnutý do pravého úhlu tak, aby se dal nasadit na přední díl. Jak byly tyto dva kusy spojeny nebo utěsněny, není dnes pro silnou korozi zřejmé. Předpokládáme, že mohly být zaletovány, například cínem. Na bocích nádoby jsou připojeny čtyři ploché průvlečky z kovových tyčinek. Jedna jejich strana je roztepána a nýtem spojena s tělem nádoby. Druhá strana prochází skrz tělo nádoby. 


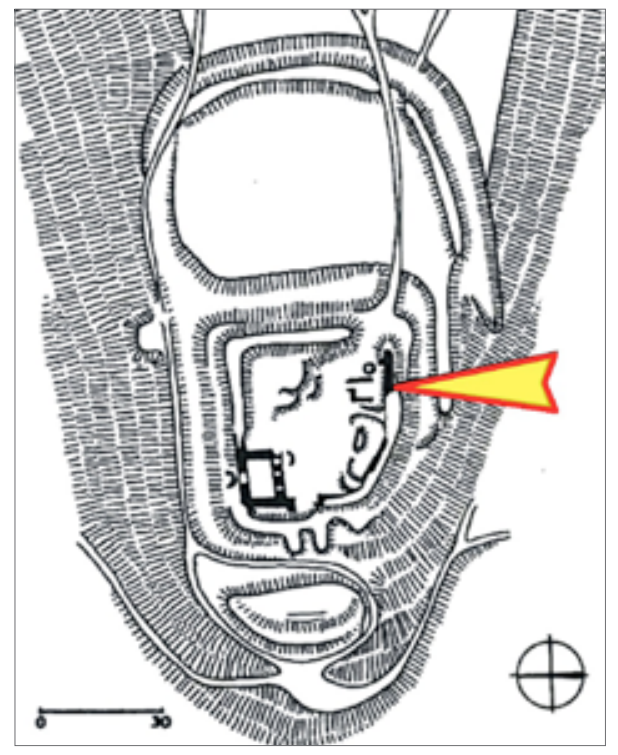

Obr. 2. Půdorys hradu Ronovce s vyznačením místa nálezu lahve. Podle Durdík 2009, 479, obr. 1035, upraveno.

Abb. 2. Grundriss von Burg Ronovec mit Kennzeichnung des Flaschenfundortes. Nach Durdík 2009, 479, Abb. 1035, bearbeitet.
K určení doby užívání ronovecké polní lahve můžeme tedy přistoupit $\mathrm{v}$ podstatě třemi způsoby. Zaprvé archeologicky, což částečně naráží na způsob, jakým byl artefakt získán. Neprofesionální výkop v roce 1958 byl sice nadšenci dokumentován, záznam je však využitelný jen omezeně. Zánikový horizont hradu leží obecně v 15. století, spíše v jeho první polovině. Druhá možnost datace za pomoci historických pramenů je omezena jejich nedostatkem. Poslední známí držitelé hradu, bratři Andělové z Ronovce, se zmiňují v první třetině 15 . století a jejich účast $\mathrm{v}$ bojových družinách té doby by nálezu lahve docela konvenovala (Štěpán 1997; Rous 2014). Hrad se uvádí výslovně pustý v polovině 16 . století (podrobněji k dějinám hradu naposledy Knápek-Mackủ 2016, 167, 175-176). Třetí možností datovat nález je pohled uměnovědný, využívající zejména srovnání s dobovou ikonografií. Zde máme k dispozici unikátní pramen vyobrazující výrobu téměř totožné kovové lahve $\mathrm{v}$ podobě několika obrázků $\mathrm{v}$ Mendelových Hausbucích pocházejících $\mathrm{z}$ počátku 15. až počátku 17. století (Amb. $317.2^{\circ}$ Folio 32 recto [Mendel I], Amb. $317.2^{\circ}$ Folio 43 verso [Mendel I]; Amb. 317. $2^{\circ}$ Folio 57 recto [Mendel I]; Amb. $317.2^{\circ}$ Folio 64 recto [Mendel I]; Amb. $317.2^{\circ}$ Folio 82 recto [Mendel I]; Amb. 317b. $2^{\circ}$ Folio 2 verso [Mendel II]; Amb. 317b. $2^{\circ}$ Folio 74 verso [Mendel II], online MHL).

Analogie $\mathrm{v}$ archeologickém materiálu nejsou dosud až na několik výjimek publikovány. Důležitým srovnávacím artefaktem k ronovecké lahvi je formálně téměř totožný nález kovové lahve z Městečka Trnávka datovaný autory výzkumu P. Kejvalem a J. Němcovou stratigraficky do 15.-16. století (ZAV Regionálního muzea v Litomyšli, 2014-2016). Celková výška trnávecké lahve činí $32 \mathrm{~cm}$ a maximální průměr výdutě $23,7 \mathrm{~cm}$. Celkové nálezové okolnosti a zhodnocení situace budou autory výzkumu publikovány samostatně. ${ }^{1}$

Na hradě Devín u Bratislavy byla objevena v roce 1975 dobře zachovalá kovová lahev při průzkumu studny V. Plachou v sektoru 20. Devínská čutora ${ }^{2}$ kruhového tvaru se skládá ze dvou vypouklých dílů, z nichž zadní díl je vyklenut méně (obr. 7:3). Na dně je opatřena třemi nožkami: dvě kolmo na rub a mezi nimi jedna kolmo na líc. Lahev je vyrobena zřejmě z železného plechu, jehož povrch je dnes chemicky stabilizován a taktéž znesnadňuje analýzy. Její rozměry činí $25,2 \mathrm{~cm}$ na výšku, $14,8 \mathrm{~cm}$ maximální výdut' a $23,2 \mathrm{~cm}$ na šířku. Lahev má místo oušek na horní polovině nanýtována dvě oka k uchycení řetízku, což je řešení, které známe z některých jiných kusů v evropských sbírkách.

Kruhová polní lahev (obr. 7:4) nalezená ve vodním př́ikopu švýcarského hradu Hallwyl ${ }^{3}$ (Kanton Aargau) je vyrobená z železného plechu (Weissblech) a datovaná do 15. století. Jmenovitě je její ztráta volně spojována s útokem bernského vojska roku 1415 (Frey 2007, 99, 262, Fundkatalog nr. 794). Hallwylská lahev je vyrobena ze dvou z plechu vytvarovaných polokoulí připojených ke střednímu pásu.

\footnotetext{
1 Děkujeme za laskavé zpř́stupnění dokumentace a konzultaci J. Němcové a P. Kejvalovi z Regionálního muzea Litomyšl, kde je nález také uložen.

2 Děkujeme za informace a poskytnutí materiálů Múzeu mesta Bratislavy a za laskavou pomoc Mgr. Kataríně Harmadyové, PhD.

3 Herzlichen Dank für die Hilfe von Georg Matter, Dr. phil., Kantonsarchäologe, Stv. Abteilungsleiter.
} 


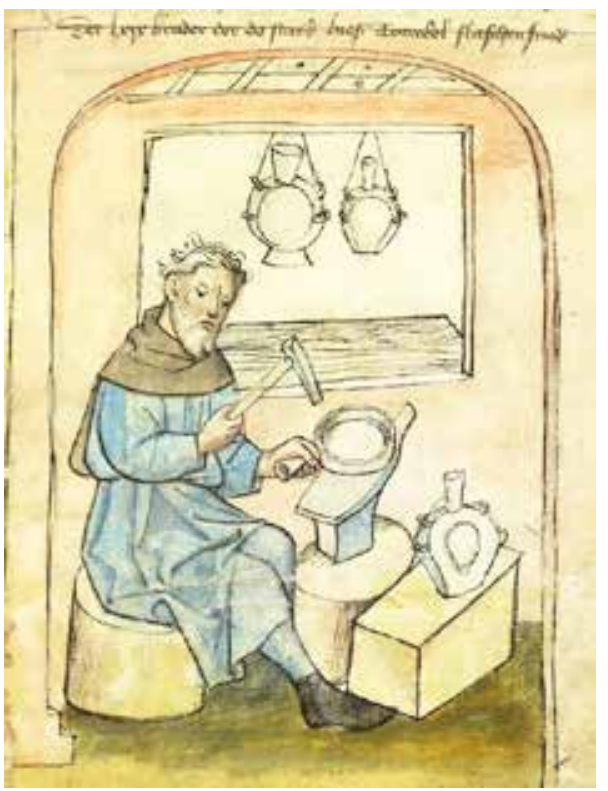

Obr. 3. Flašnéř na dobovém vyobrazení okolo roku 1425 v Hausbuch der Mendelschen Zwölfbrüderstiftung (Band 1), Nürnberg, Mendelsche Zwölfbrüderstiftung, list Amb. $317.2^{\circ}$ Folio 32 recto (Mendel I, výřez). Stadt Bibliothek Nürnberg. Dostupné z: https://hausbuecher.nuernberg.de/. Abb. 3. Flaschner auf einer zeitgenössischen Darstellung um das Jahr 1425 im Hausbuch der Mendelschen Zwölfbrüderstiftung (Band 1), Nürnberg, Mendelsche Zwölfbrüderstiftung, Blatt Amb. 317.2 ${ }^{\circ}$ Folio 32 recto (Mendel I, Ausschnitt). Stadt Bibliothek Nürnberg. Abrufbar unter: https://hausbuecher.nuernberg.de/.

\section{Ikonografické prameny k lahvím}

Pro představu o šíři užívání polních lahví můžeme asi nejlépe využít ikonografické památky, nebot' jiných pramenů máme poskrovnu. Vcelku známá jsou vyobrazení polních lahví ve spojení s poutníky, apoštoly a svatými, která se běžně vyskytují od 14. století. Z dvorského prostředí pochází vyobrazení polní lahve například v Codexu Mannesse (obr. 4:S), v němž ji na listě $314(\mathrm{Bl} .314 \mathrm{v})$ podává Günther von dem Vorste své dámě (srovnej Gross 1988, 104).

Dobová vyobrazení zachycují z velké části nádoby keramické, dřevěné a usňové, jak napovídá jejich ztvárnění, ale i srovnatelné archeologické nálezy. Pro keramické tvary těchto nádob bylo v české (Fröhlich 2012) i zahraniční literatuře porůznu v rámci keramických souborů publikováno množství těchto artefaktů bud'to př́imo pod označením poutnické nebo polní lahve (Pilgerflasche, Feldflasche; namátkou Stoll 1933; Wehmer 2015, 231 s odkazy, Abb. 47). Tato skupina lahví se $\mathrm{v}$ podstatě neliší od čutor vyobrazených $\mathrm{v}$ různém sociálním kontextu. Zvláštním př́íkladem miniaturní čutory je takzvaná Menasova ampule přivezená ve 13 . století na hrad Rychleby z východního Středomoří, patrně v souvislosti s výpravami do Svaté země (Kouřil 2002, 15-19; souhrnně Krampl 2007).

Připomeňme na okraj také poutní odznaky ve formě funkčních i schematizovaných lahviček a čutor z kovu či keramiky (Slivka 1998, 307-308; Jarecki 1999; Schneider 1999). Ty, vyjma funkce odznaku s jeho ochrannými vlastnostmi, často plnily i účel přepravní - na svěcenou vodu či olej, jak to máme doloženo např́íklad díky kovovým lahvičkám od poutního místa - hrobu sv. Tomáše Becketa v anglickém Canterbury (Velímský 1998, 436). „Ampule“ s oleji přinášeli poutníci přes jižní Evropu z biblických oblastí Palestiny, Sýrie, Egypta a dalších přilehlých oblastí (Niederle 1933, 45). Tyto ampulky byly vyráběny z čistého cínu bez dalších příměsí (Haasis-Berner 2003, 20). Ze známých nálezů zmiňme alespoň tři nacházející se v Museum of London (MoL, dostupné online) - olověný exemplář zdobený erby ze 14. století (inv. č. 8816), dále pak další vyzvednutý z řeky Temže v Londýně (inv. č. 93.215/2, 15. století) a část kadlubu sloužícího k odlití podobné ampule (inv. č. 11053, 13. století).

Usňové čutory v ikonografii nacházíme vyobrazené nejčastěji při hospodářských pracích na poli, při kratochvilných lovech šlechty, ale i při jejich hostinách v interiérech domů a hradů. Je to logické, nebot' lahve z tohoto materiálu patří k nejlehčím a také nejdostupnějším.

Výrobu takové flašky, byt' na př́kladu ,chocholu“ (klenotu) pro přilbici nám popisuje dobový autor Cennino Cennini ve své Knize o uměni středověku z roku 1437 (Cennini 1946, 202): „(...) musiš nejdřive míti bílou kůži, vydělanou jen borůvčím nebo duběnkami; rozprostři takovou kůži a vykresli svi̊j chochol, jak jej chceš mit. A kresli hned dva a sešij je pospolu, leč po jedné straně ponech tolik mista, aby se tam mohl nasypati pisek; a hůlčičkou jej tak upěchuj, aby to bylo plné. Když to je tak hotové, vystav to slunci na několik dní. Když je to proschlé, písek vysyp (...).“ 

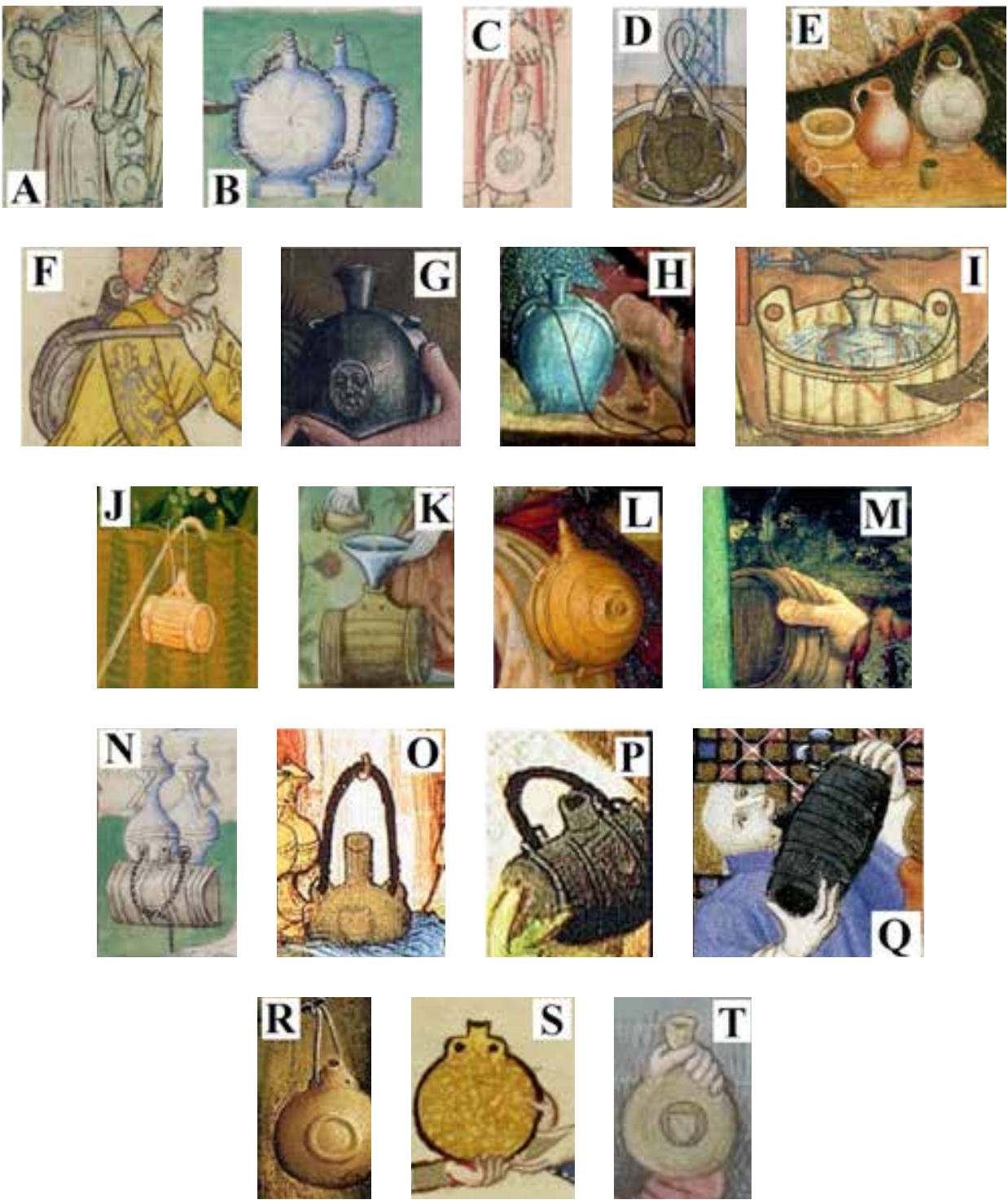

Obr. 4. Vybraná dobová vyobrazení tzv. polních lahví. A-I - kovové, J-M - dřevěné, N-Q - usňové, R-T - keramické a neurčitelné. A - Speculum humanae salvationis, Karlsruhe 3378, Německo okolo 1350, Badische Landesbibiliothek Karlsruhe; B, N - Guillaume de Machaut, Poésies. Français 1586, Bibliotheque nationale de France, Francie 1350-1355; C - Österreichische Nationalbibliothek, Fideikommißbibliothek, kolem 1419; D - Hugo von Trimberg, Der Renner, počátek 15. století; E - scéna Narození Krista na kvadriptychu z Musea Mayera van den Bergha, Antverpy, konec 14. století; F - Hofämterspiel, hrací karta s postavou číšníka, Kunsthistorisches Museum Wien, Kunstkammer, 5111, kolem 1455; G - Mistr z Mariapffar, deskový obraz Loučení apoštolů (výřez), Graz, Universalmuseum Joanneum (IN 383); H - Deskový oltář farního kostela v Maria Gail (Rakousko, Korutany) - výřez (1505-1515); I - Mendelův Hausbuch, Amb. 317.2 ${ }^{\circ}$, fol. 88v, Mendel I; J - Narození Krista, detail z díla Friedricha von Villach, 1420-1430; $K$ - Kniha jednoduchých léčiv, Bibliotheque nationale de France, BNF Fr. 12322, fol. 187v, 1520-1530; L - detail z díla Jörga Breu staršího, 1500-1502; M - Rozloučení tyrolských apoštolů, 1510-1520, archiv autorů; O-Q - Kniha o lovu Gastona Phoeba, 1405-1410; R - Grabowský oltář, Mistr Bertram, 1379-1383, Hamburger Kunsthalle, Hamburg; S - Codex Manesse (Grosse Heidelberger Liederhandschrift), Cod. Pl. Germ. 848, fol. 314v, 1300-1340; T - Hodinky Karla d'Angoulême, Bibliotheque nationale de France, BNF Latin 1173, fol. $4 \mathrm{v}, 1475-1500$.

Abb. 4. Ausgewählte zeitgenössische Darstellungen von sog. Feldflaschen. A-I - aus Metall, J-M - aus Holz, N-Q - aus Leder, R-T - keramische und unbestimmbare. A - Speculum humanae salvationis, Karlsruhe 3378, Deutschland um 1350, Badische Landesbibiliothek Karlsruhe; B, N - Guillaume de Machaut, Poésies. Français 1586, Bibliotheque nationale de 
France, Frankreich 1350-1355; C - Österreichische Nationalbibliothek, Fideikommißbibliothek, um 1419; D - Hugo von Trimberg, Der Renner, Anfang 15. Jhdt.; E - Szene der Geburt Christi auf dem Quadriptychon aus dem Museum Mayer van den Bergh, Antwerpen, Ende 14. Jhdt.; F - Hofämterspiel, Spielkarten Figur eines Kellners, Kunsthistorisches Museum Wien, Kunstkammer, 5111, um 1455; G - Meister von Mariapfarr, Tafelbild Apostelabschied (Ausschnitt), Graz, Universalmuseum Joanneum (IN 383); H - Tafelaltar der Pfarrkirche in Maria Gail (Österreich, Kärnten) - Ausschnitt (1505-1515); I - Mendels Hausbuch, Amb. 317.2 ${ }^{\circ}$, fol. 88v, Mendel I; J - Geburt Christi, Detail aus dem Werk von Friedrich von Villach, 1420-1430; K - Buch einfacher Heilmittel, Bibliotheque nationale de France, BNF Fr. 12322, fol. 187v, 1520-1530; L - Detail aus dem Werk von Jörg Breu d.Ä., 1500-1502; M - Abschied der Tiroler Apostel, 1510-1520, Archiv der Verfasser; O- $Q$ Das Buch der Jagd von Gaston Phoebus, 1405-1410; R - Grabower Altar, Meister Bertram, 1379-1383, Hamburger Kunsthalle, Hamburg; S - Codex Manesse (Große Heidelberger Liederhandschrift), Cod. Pl. Germ. 848, fol. 314v, 1300-1340; T - Stundenbuch von Karl von Angoulême, Bibliotheque nationale de France, BNF Latin 1173, fol. 4v, 1475-1500.

Stejným způsobem lze postupovat i u vyvařované lahve, kdy je tato místo vytvrzení na slunci ponořena do horké vody či včelího vosku a následně pozvolna vysušena. Po vysypání písku a vypláchnutí se vylije včelím voskem, který zamezí protékání skrze švy. Lze zároveň šít i složitější tvary, stačí pouze vystřihnout z usně více dílů. Takovéto lahve byly autory článku experimentálně ušity dvě (soudkovitá o objemu 0,51 a kulovitá o objemu 0,751 ) a z funkčního hlediska se nanejvýš osvědčily. Důležitá je ovšem opatrnost při manipulaci, protože vyvařené lahve jsou zároveň křehké. Je-li lahev silou zmáčknuta, naruší se vosková vnitřní vrstva a lahev může protékat. Tento problém však lze vyřešit opětovným vylitím vnitřku lahve voskem.

Z publikovaných nálezů zmiňme alespoň soudkovitou lahev zdobenou erby z pozdního 14. století uloženou v Museum of London (inv. č. BC72/83/1996) s rozměry v. $18 \mathrm{~cm}$, d. 19,5 cm a hl. $8 \mathrm{~cm}$; dále podobnou menší čutorku s plošným vegetabilním dekorem z 15 . století (inv. č. A10640) či novověký exempláŕ ze 17. století s jen decentní výzdobou (inv. č. 82.149; vše online MoL). Další novověké lahve z Nizozemí publikoval O. Goubitz $(2009,107)$ a nelze nezmínit ani exempláře z poměrně unikátního souboru potopené karaky Mary Rose ze dne 19. července 1545 u ostrova Wight (Marsden 2003). Nejšířeji se usňovým lahvím věnoval už před sto lety O. Baker (1921).

V ikonografii se vyskytují dva druhy dřevěných čutor: skládané z dřevěných dýh (obr. 4:J, K), které jsou jak soudkovité, tak kruhové stavby těla, a soustružené, které bývají vždy oválné (obr. 4:L). Vysoustružené pak nesou na lícové straně různý počet plastických kruhových lišt připomínajících terč, což bývá někdy napodobováno i na čutorách keramických a kovových (srovnej obr. 4:A, C-E, L, R). Z toho důvodu, především u nepř́liš detailních obrazových pramenů starších 15. století nelze vždy zcela jistě určit výrobní materiál. Nutno zde zmínit, že u archeologických nálezů dřevěných a keramických fragmentů lahví, pokud se nenajde větší torzo, nemusí být vůbec rozeznáno, že jde o součást čutory.

Společným výzdobným prvkem čutor z výše uvedených materiálů bývají často plastické erby. Jejich počet je odvislý od velikosti lahve a jejího dalšího zdobení. Zda šlo jen o výzdobný prvek s neutrálními znaky či př́ímo vyobrazení urozenosti majitele lahve, nelze za současné znalosti této problematiky určit (obr. 4:O, P, T). Mohou se vyskytnout ale i jiné typy zdobení, at' už v podobě geometrických tvarů, vegetatibilních motivů či maskaronů (obr. 4:G).

Kovové lahve, alespoň ty, u kterých nám vyobrazení dovoluje materiál s velkou pravděpodobností určit, se často objevují u osob představujících ozbrojence (obr. 4:A). K tomu se pojí jeden z patrně nejstarších záznamů o kovových lahvích ve vojenském prostředí. Jde o zápis z roku 1384, kdy se ,an harnusch“ čili ve zbrojnici pruského řádového Marienburgu uvádí 18 cínových lahví, 20 železných lahví a dva cínové stojany, nebo podstavce (Śliczyńska 2016, 53). $\mathrm{Z}$ českých a moravských hradů jsou kovové lahve zachyceny zejména v soupisech ze 16. století. Tak na Helfštejně jsou roku 1552 (ve sklepě) mezi velkým množstvím zbraní, potřeb pro tažení, nádobím a náŕadím dvě ,flašky plechové“ (Hrubý 1927, s. 284). Podobný obraz ukazuje soupis z Velkého Meziř́ičí, kde byly s doprovodným materiálem ve sklepě uloženy tři ,flaše plechový bílý (po 2 zl) a mezi stolovním náčiním 1 flaše plechová velká“،, opět v ceně 2 zl (Hrubý 1927, 295-296). Opevněný zámek v Kostelci nad Černými lesy byl také vybaven zbrojnicí s potřebami k polnímu tažení, v níž rovněž nalezneme ,čtyři cínové flaše ve vojenském stolečku, dvě flaše 


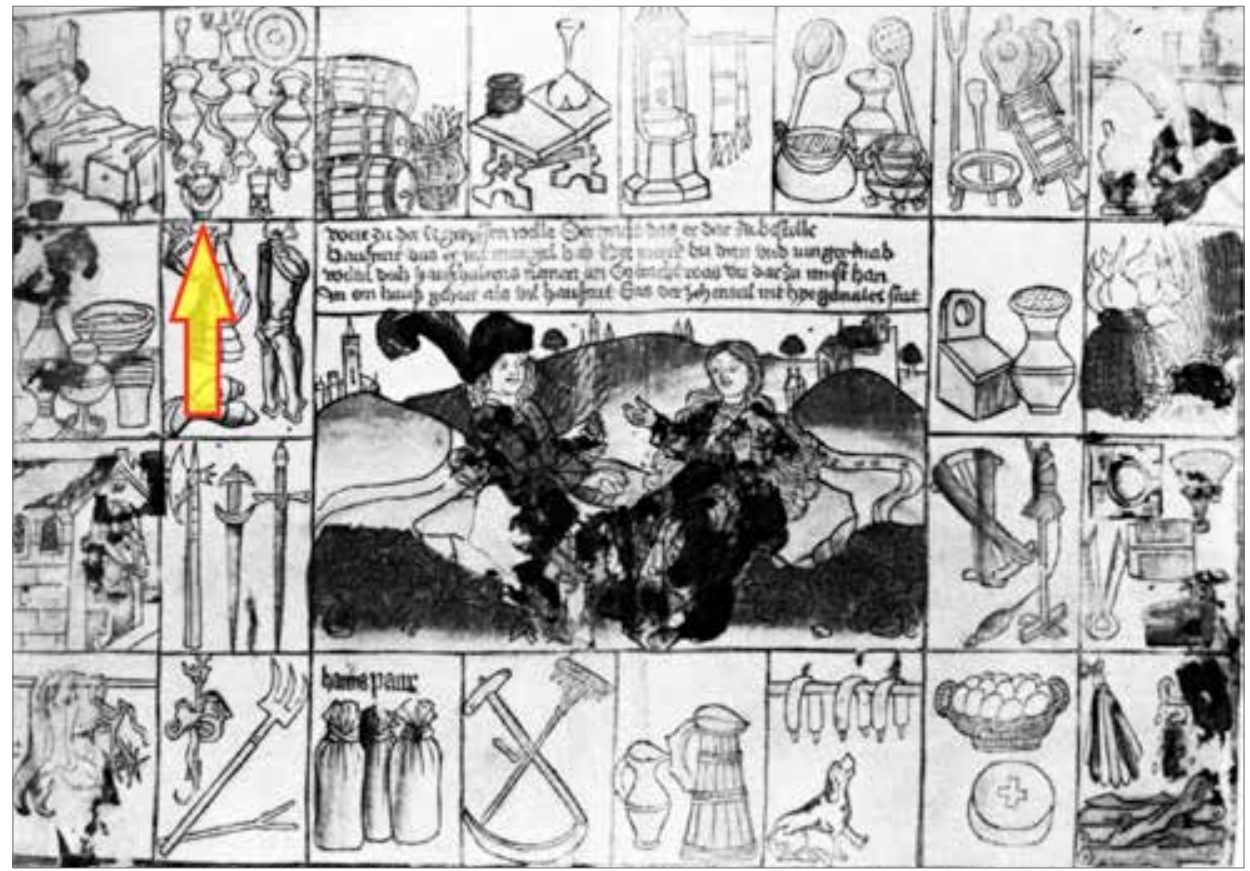

Obr. 5. Výbava měšt’anské rodiny. Dřevořezba Hanse Paura okolo roku 1480. Podle Kahsnitz-Brandl 1984, 13, Abb. 2. Abb. 5. Ausstattung einer bürgerlichen Familie. Holzschnitt von Hans Paur um das Jahr 1480. Nach Kahsnitz-Brandl 1984, 13, Abb. 2.

měděné vojenské, tři cínové taliřre a čiše, jednu cínovou mísu a jednu cínovou konvici“" (Holasová 2005, 65).

Velmi instruktivním vyobrazením vojenského užití kovových lahví je markytánka nesoucí zjevně kovovou čutoru hned za zástupem těžkooděnců do bitvy u Sempachu (obr. 6:A) a ze švýcarského vojenského prostředí pochází také nález z hradu Hallwyl, který menší velikostí odpovídá některým dobovým vyobrazením z druhé poloviny 15. století (Embleton 1992, 5-7). Okolo roku 1500 zachycuje kresba střelce střežící zákop jakéhosi lehkého opevnění, kteří mají dvě plechové, nebo cínové čutory (obr. 6:B) položeny v dosahu (Eyb 1500; list 14, evidovaný jako Bl. b. recto). Několik velkoobjemových kovových čutor je zachyceno v plném užívání ve vojenském táboře na obraze vojska Karla V. ležícího roku 1546 před Lauingenem (obr. 6:D). $\mathrm{Z}$ jiného, ovšem př́ibuzného prostředí pochází vyobrazení lahví kruhového tvaru s podstavcem a oušky na plecích zdobených erby. Třemi takovými lahvemi obdarovává anglický král Zikmunda Lucemburského v Calais roku 1416 na ilustraci vídeňského rukopisu Kniha císaře Zikmunda (Bartlová et al. 2014, 609). Z kresby se dokonce zdá, a bylo by to logické, že jde o drahocenné, snad pozlacené kusy, podobně jako např́ílad dochovaná cestovní lahev sv. Ruperta.

Často nacházíme polní lahve v rámci vyobrazení scén z kratochvilných oblastí šlechty, jako jsou lovy (variace Knihy o lovu Gastona Phoeba, obr. 4:O-Q) či hostiny (obr. 4:B, N). Na vyobrazeních z měštanského prostředí je pak nacházíme v kádích pod stolem, kde je jejich obsah chlazen ve studené vodě (obr. 4:D, I), prrípadně i přímo v domovních inventáŕích (obr. 5). Nejčastěji jde o kulaté kovové a soudkovité usňové varianty. Poslední oblast ikonografie, kde se s čutorami lze setkat, lze označit jako žánrovou (obr. 4:F, T). Čutory zde tvoří pouze doplněk bez výraznějšího významu v rámci vyobrazené scény. 


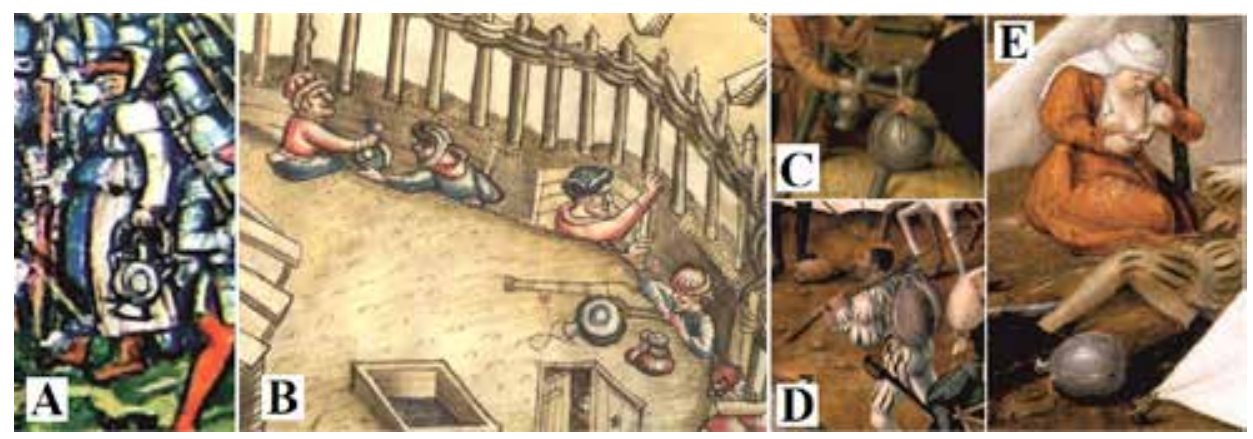

Obr. 6. Ukázky polních kovových lahví ve vojenském prostředí. A - žena doprovázející zbrojný houf v bitvě u Sempachu, výřez z Luzerner Chronik (1513), s. 32-33; digitalizovaná verze z originálu v Korporation Luzern (depositum at the Zentralund Hochschulbibliothek Luzern); B - Kriegsbuch Ludwiga von Eyb, 1500, výřez; C-E - třri výřezy z vyobrazení ležení Karla V. před Lauingenem ve Švábsku, Mathias Gerung, 1551, malba na dřevo, originál uložen v Heimathaus Lauingen, nr. 482. Abb. 6. Beispiele für Metallflaschen in militärischer Umgebung. A - die Wehrschar in der Schlacht bei Sempach begleitende Frau, Ausschnitt aus der Luzerner Chronik (1513), S. 32-33; digitalisierte Version des Originals der Korporation Luzern (Depositum in der Zentral- und Hochschulbibliothek Luzern); B - Kriegsbuch von Ludwig von Eyb, 1500, Ausschnitt; C-E - drei Ausschnitte aus der Darstellung des Lagers Karls V. vor Lauingen in Schwaben, Mathias Gerung, 1551, Malerei auf Holz, das Original wird aufbewahrt im Heimathaus Lauingen, Nr. 482.

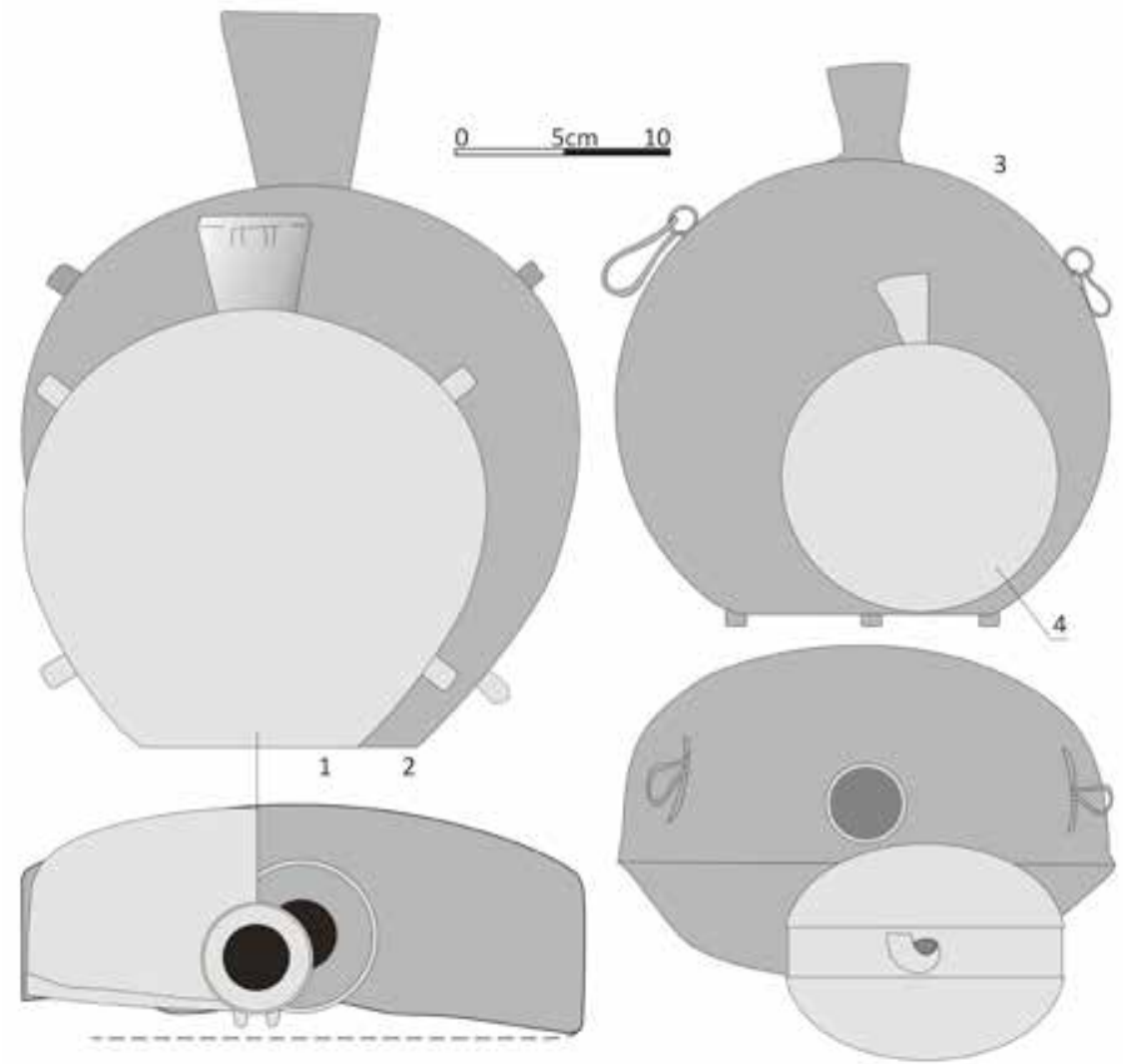

Obr. 7. Srovnání kovových lahví z archeologických nálezů. 1 - hrad Ronovec; 2 - Městečko Trnávka; 3 - hrad Devín (Slovensko); 4 - hrad Hallwyl (Švýcarsko).

Abb. 7. Vergleich der Metallflaschen aus archäologischen Funden. 1 - Burg Ronovec; 2 - Markt Thürnau; 3 - Burg Theben (Slowakei); 4 - Burg Hallwyl (Schweiz). 
Středověká vyobrazení zachycují i zajímavé detaily, mimo jiné dřevěné zátky ústí (Mayer van den Bergh, Narození Ježíše, kolem 1380, nebo Mistr Karlsruhských pašijí, panel „svlékání Krista“, kolem 1440), dochované také u usňových lahví ve vraku Mary Rose (obr. 4:B, E, F, I, L).

Pozdní doklady vojenského užívání čutor pocházejí z počátku třicetileté války, kdy například zbrojnice na pražském hradě vydávala přes 4000 usňových pouzder na lahvice. Roku 1620 bylo vydáno dvěma regimentům celkem 380 čutor a usňových povlaků na čutory (Líva 1951, 116) a konečně roku 1621 měly být z Prahy vydány do Hradce Králové hejtmanu Taxisovi polní lahve v počtu 140 kusů (Líva 1951, 184). Je možné, že jde o zbytky hotovostní výstroje shromažd'ované pro protiturecké války v Uhrách. Oblibě polních lahví u vojsk konce 15. a 16. století by odpovídal jejich relativně velký výskyt v dobových vyobrazeních. Pro tuto myšlenku máme také podpůrné zmínky v dobových pramenech. Když se roku 1611 pořizoval soupis vybavení smiřického zámku v Kostelci, nacházela se ve věži brány rystkomora obsahující mimo jiné tři vojenské stany, vojenské lůžko a zejména potřebné nádobí: čtyři cínové flaše ve vojenském stolečku a dvě vojenské flaše měděné (soupis z roku 1611 podle Holasová 2005, 65). Roku 1618 se zde nacházela také „truhla vysoká se čtyřmi cejnovými flašemi na vosla“ (Prchal 2015, 103), šlo snad o velké lahve, jaké vidíme např́íklad ve vojenském táboře Karla V. u Lauingenu.

Technické řešení plechových polních lahví mělo oproti ostatním materiálům nevýhodu řešení povrchové úpravy, př́ípadně spojů na nádobách. Povrchovou úpravu bílého plechu nám prameny nesdělují, nicméně v ikonografii jsou nádoby zobrazené se „stř́ibřitým“ povrchem, což by mohlo značit pocínování. Ostatně to se objevovalo například na částech středověkých zbraní (Žákovský 2014) a výše jsme zmínili doloženou práci flašnéřů s pocínovaným plechem. Stejného názoru byl, bez znalosti souvislostí, také nálezce ronovecké lahve Josef Čapek. Vzhledem ke stavu dochovaných nálezů nejsme zatím schopni na tuto zajímavou otázku s jistotou odpovědět, nicméně po konzultacích se současnými výrobci považujeme pocínování za velmi pravděpodobné.

\section{Typologie}

Po nastíněném exkurzu po pramenech archeologických a ikonografických lze definovat základní tvary polních lahví. Svůj funkčně dokonalý tvar získaly už v době mladšího pravěku a ten se udržel prakticky dodnes. Nejčastěji se setkáváme s tvary kulovitými, více či méně zploštělými. Známé kulovité flašky se vyráběly ze všech dostupných materiáli̊. Vedle toho se vyskytují tvary soudkovité, lišící se spíše v průřezu (od kulatých přes oválné, hranaté až po trojúhelné). Tyto byly vyráběny nejčastěji z usní nebo byly skládané z dřevěných dýh.

Ronovecká čutora patří svou morfologií k nejběžnějším kulovitým a plošším tvarům, a představuje tedy typický předmět středověké společnosti. Jejím majitelem mohl být kdokoli z hradu.

\section{Závěrem}

Lze konstatovat, že kovové „polni““ lahve byly spolu s lahvemi z jiných materiálů běžnou a nedílnou součástí středověkého života. Objevovaly se hojně ve všech sociálních prostředích. Celokovové lahve se objevily nejspíše až od 14. století a rozmach jejich používání nastal v 15.16. století, přičemž se udržují až dodnes. Do jisté míry to patrně souvisí s jejich užíváním v militárním prostředí, kde musela být ceněna odolnost těchto kusů. Objevují se však nepochybně také ve výbavě panských sídel a měštanských domů, kde sloužily k přenášení tekutin (vína?) ze sklepů. Výhodou zde opět patrně byla jejich odolnost a nenasákavost. Důležitá u kovových nádob byla pravděpodobně také možnost výroby nádoby o větším objemu při relativně nízké vlastní váze a zachování potřebné odolnosti výrobku. 


\section{Literatura}

BAKER, O., 1921: Black Jacks and Leather Bottells. Being some account of Leather Drinking Vessels in England and incidentally of other Ancient Vessels. London.

BARTLOVÁ, M., ed., et al., 2014: Husitské století. Praha.

CENNINI, C., 1946: Kniha o umění středověku. Il Libro dell’Arte, A. D. 1437 (ed. Vladimír Žikeš). Praha.

CRONE, A.-CAMPBELL, E., 2005: A Crannog of the First Millennium, AD: Excavations by Jack Scott at Loch Glashan, Argyll, 1960. Edinburgh.

ČAPEK, J., 1958: Zápisník vlastivědného kroužku pro Ronovec a okolí. Rukopis z let 1958-1963, uložen v muzeu spolku v Dolní Krupé (kopie v MV Havl. Brod, p. o., v archivu archeologických lokalit).

DURDÍK, T., 2009: Ilustrovaná encyklopedie českých hradů. Praha.

DÜRRICH, W. M., 1846: Die Grabfunde von Oberflacht. Jahreshefte des Wirtenbergischen Alterthums-Vereins. Bd. 1. Heft 1-12, Taf. IX.-XI. Stuttgart 1844-1869.

EMBLETON, G., 1992: Dress for the woman of our company. Dragon No. 4. The compagy of Saint George. Onnes.

FREY, P., 2007: Das Stammhaus der Herren von Hallwyl. Baden.

FRÖHLICH, J., 2012: Keramické čutory v jihozápadních Čechách, ASČ 16, 393-399.

FURGER, A., Hrsg., 1996: Die Schweiz zwischen Antike und Mittelalter. Archäologie und Geschichte des 4. bis 9. Jahrhunderts. Archäologie und Kulturgeschichte der Schweiz 4. Zürich.

GOUBITZ, O., 2009: Purses in Pieces. Archaeological finds of late medieval and 16th-century leather purses, pouches, bags and cases in the Netherlands. Zwolle.

GROSS, U., 1988: C - Bilder und Sachen. In: Codex Manesse. Die Große Heidelberger Liederhandschrift. Texte - Bilder - Sachen. Katalog zur Ausstellung vom 12. Juni bis 4. September 1988 in der Universitätsbibliothek Heidelberg (Mittler, E.-Werner, W., Hrsg.), 68-112. Heidelberg.

HAASIS-BERNER, A., 2003: Pilgerzeichen der Hochmitttelalters. Würzburg.

HEGER, L., 1957: Saga o Grettim. Praha.

HEJNA, A., 1970: Tábor. Praha.

HOLASOVÁ, A., 2005: Kostelec nad Černými lesy ve světle inventáře z roku 1611 s přihlédnutím k inventár̆ům pozdějším, Východočeský sborník historický 12, 45-71.

HRUBÝ, F., 1927: Selské a panské inventáře v době předbělohorské, ČČH 33, 21-59, 263-306.

HRUBÝ, V., 1955: Velkomoravské pohřebiště „Na Valách“. Praha.

JARECKI, H., 1999: Feldflaschen - Pilgerflaschen: Anmerkungen zu einer wenig beachteten Fundgruppe, Archäologische Berichte aus Sachsen Anhalt 1, 213-231.

JUNG, H., 1970: 3000 Jahre Bocksbeutel. Der siegeszug eine Weinflasche. Würzburg.

KAHNSNITZ, R.-BRANDL, R., 1984: Aus dem Wirtshaus Zum Wilden Mann. Funde aus dem mittelalterlichen Nürnberg. Katalog zur Ausstellung des Germanischen Nationalmuseums 5. Juli bis 16. Sept. 1984. Nürnberg.

KAVÁN, J., 1962: Nálezy dřevěných nádob a nábytku ze 13. st., PA LIII, 219-239.

KNÁPEK, A., 2019: 60 let průzkumů hradu Ronovce, Hláska, v tisku.

KNÁPEK, A.-MACKŮ, P., 2016: Unikátní součást zbroje z hradu Ronovce (okres Havlíčkův Brod) - Ein einzigartiger Bestandteil einer Rüstung von Burg Ronovec (Bezirk Havlíčkův Brod), AH 41, 167-180.

KOUŘIL, P., 2002: Menasova ampule z hradu Rychleby (?) ve Slezsku. In: Pro arte. Sborník k poctě Ivo Hlobila (Prix, D., ed.), 15-19. Praha.

KRAMPL, T., 2007: Ampulka svätého Menasa - Die Ampulle des heiligen Menas, Annales Musei Nationalis Slovaci Archaeologia Supplementum 2, 139-151.

LÍVA, V., ed., 1951: Prameny k dějinám třicetileté války. Regesta fondu Militare Archivu ministerstva vnitra ČSR v Praze. Díl III. 1618-1625. Praha.

MARSDEN, P., 2003: Sealed by Time: The Loss and Recovery of the Mary Rose. The Archaeology of the Mary Rose. Volume 1. Portsmouth.

MARZOLI, D., 1989: Die Bronzefeldflaschen in Italien. Prähistorische Bronzefunde 4: Abteilung II. München.

NIEDERLE, L., 1933: Ploska (čutora) z hrobů v Starém Městě. In: Památky archeologické, skupina pravěká. Nové řady ročník III. (díl XXXIX), 44-46. Praha.

OTRUBA, G., 1970: Zur Geschichte des goldschmiedehandwerks in Österreich: bis zum Ausgang des 16. Jahrhunderts, Zeitschrift für Firmengeschichte und Unternehmerbiographie 15, č. 2/3, 97-148.

PLANCK, D., 1983: Das Freilichtmuseum am Rätischen Limes im Ostalbkreis. Stuttgart. 
POLLA, B., 1962: Stredoveká zaniknutá osada na Spiši (Zalužany). Archaeologica Slovaca fontes. Tomus IV. Bratislava.

PRCHAL, V., 2015: Společenstvo hrdinů. Praha.

ROUS, P., 2014: Anděl z Ronovce, Havlíčkobrodsko 28, 273-280.

SCHNEIDER, K., 1999: Bocksbeutel: Platt-, Feld- und Pilgerflaschen: ihre Geschichte und Verbreitung. Volkach. Selbstverlag.

ŚLICZYŃSKA, J. E., 2016: Lebensmittelvorräte und deren aufbewahrug auf dem deutschordensburg in Elblag (FR. Elbing) um die wende zum 15. Jahrhundert, Epocha przeslości XII, 45-55.

SLIVKA, M., 1998: Stredoveký homo viator (Slovensko vo vzt’ahu k medzinárodným pútnym miestam) Der mittelalterliche homo viator (Die Beziehumg der Slowakei zu den internationalen Wallfahrtsorten), AH 23, 303-320.

SOJÁK, M., 2015: Spiš. Svedectvo archeólogie. Nitra.

STOLL, H., 1933: Mittelalterliche Tonfeldflaschen aus Schwaben, Germania 17, 210-213.

ŠTĚPÁN, V., 1997: Andělové z Ronovce, Havlíčkobrodsko 13, 153-157.

VELÍMSKÝ, T., 1998: K nálezům středověkých poutních odznaků v českých zemích - Zu den Funden der mittelalterlichen Pilgerzeichen aus den böhmischen Ländern, AH 23, 435-455.

TIETZE, H., 1912: Die kirchlichen Denkmale der Stadt Salzburg. Wien.

WEHMER, M., 2015: Keramik am Übergang vom Spätmittelalter zur frühen Neuzeit. Ein Überblick zur Entwicklung der Gefäßformen und Warenarten in Nordhausen während des 15. und 16. Jahrhunderts. Beiträge zur Geschichte aus Stadt und Landkreis Nordhausen Bd. 40. Nordhausen.

WINTER, Z., 1890: Kulturní obraz českých měst. Díl první. Praha.

- 1906: Dějiny řemesel a obchodu v Čechách. Praha.

ŽÁKOVSKÝ, P., 2014: Tesáky a problematika jednosečných zbraní středověku a raného novověku. Disertační práce, ulož. na FF MU, Brno.

\section{Internetové zdroje}

EYB 1500 - Ludwig von (der Jüngere), 1500: Kriegsbuch. Rukopis knihy uložen v Universitätsbibliothek Erlangen-Nürnberg, Hauptbibliothek (Sigel: 29). Digitalizovaná kopie rukopisu UER MS. B 26. Dostupné z: http://digital.bib-bvb.de/webclient/DeliveryManager?custom_att_2=simple_viewer\&pid=4555786, cit. 19. 7. 2019.

MHL - Die Mendelschen und Landauerschen Hausbücher. Dostupné z: https://hausbuecher.nuernberg.de/, Amb. $317.2^{\circ}$ Folio 32 recto (Mendel I), Amb. $317.2^{\circ}$ Folio 43 verso (Mendel I); Amb. $317.2^{\circ}$ Folio 57 recto (Mendel I); Amb. 317.2 $2^{\circ}$ Folio 64 recto (Mendel I); Amb. 317.2 ${ }^{\circ}$ Folio 82 recto (Mendel I); Amb. 317 b. $2^{\circ}$ Folio 2 verso (Mendel II); Amb. 317b. $2^{\circ}$ Folio 74 verso (Mendel II), cit. 24. 1. 2019; Amb. $317.2^{\circ}$ Folio 88 verso Mendel I, cit. 19. 7. 2019.

MoL - Museum of London. Dostupné z: https://collections.museumoflondon.org.uk/online, cit. 19. 7. 2019.

MWP - Muzeum Wojska Polskiego. Cínová lahev ze 17. století. Dostupné z: http://www.muzeumwp.pl/ emwpaedia/flasza.php, cit. 19. 7. 2019.

\section{Zusammenfassung}

\section{Mittelalterliche „Feldflaschen“ aus Metall am Beispiel eines Fundes von Burg Ronovec}

Das Vorkommen von Feldflaschen ist schon seit der jüngeren Urzeit dokumentiert. Ihre Formgebung hat sich im Mittelalter auf zwei Varianten stabilisiert, die sich lediglich in Details und im Fassungsvermögung voneinander unterscheiden. Die typischste Form war eine runde oder ovale Flasche, deren Schultern entweder flach oder mehr oder weniger konvex waren. Eine typische Erscheinungsform war auch die Form mit einer geraden Rückseite und einer ausgebauchten Vorderseite, was den Transport erleichterte und gleichzeitig das größte Fassungsvermögen beibehielt. Ein weiterer beliebter Typ waren fassartige Flaschen, deren Variabilität durch die Form des Querschnitts der Seitenflächen gegeben war (von oval bis dreieckig und kantig).

Die typischsten für die Herstellung dieser Artefakte verwendeten Materialien waren Leder, Holz, Keramik und Metall, einschließlich Buntmetalle. Im ikonographischen Material begegnen 
wir allen Materialtypen und in allen Alltagsszenen - angefangen bei der Feldarbeit über das Bürgertum und den Adel bis hin zu Pilgern und biblischen Szenen.

Eisenflaschen begegnen wir in der Ikonographie ab dem 14. Jahrhundert, ein hohes Maß ihrer Verwendung verzeichnen wir im 15.-16. Jahrhundert. Eine Metallflasche wurde auch auf Burg Ronovec entdeckt (Tschechien, Bezirk Havlíčkův Brod, Abb. 1). Leider wurde sie im Jahr 1958 gefunden, als sie im Rahmen einer den damals herrschenden Verhältnissen Tribut zollenden archäologischen Grabung gehoben wurde, also ohne näher beschriebene Fundumstände. Die Burg ist höchstwahrscheinlich im Laufe der ersten Hälfte des 15. Jahrhundert untergegangen, was auch mit dem Vorkommen dieses Flaschentyps in der Ikonographie korrespondierte, einschließlich des bekannten Bildes eines Flaschners in der Handschrift Die Mendelschen und Landauerschen Hausbücher.

Ähnliche Feldflaschen aus Blech sind uns auch von weiteren Fundstellen bekannt, beispielsweise aus Markt Türnau (Tschechien; Abb. 7:2), von der Thebener Burg (Slowakei; Abb. 7:3) oder von Burg Hallwyl (Schweiz, Abb. 7:4).

Die vorliegende Arbeit hat zum Ziel, die Problematik der Feldflaschen zu eröffnen, da sicherlich noch eine Fülle weiterer von ihnen entweder unbearbeitet oder vergessen in den Depots der Museen liegen und bei künftigen archäologischen Grabungen sicherlich noch weitere entdeckt werden.

Mgr. Aleš Knápek, Katedra archeologie Filozofické fakulty Univerzity Hradec Králové, Rokitanského 62, 50003 Hradec Králové, Česká republika, knapek.a@gmail.com

Mgr. Pavel Macků, Národní památkový ústav, územní odborné pracoviště v Telči, Hradecká 6, 58856 Telč, Česká republika, macku.pavel@npu.cz 
